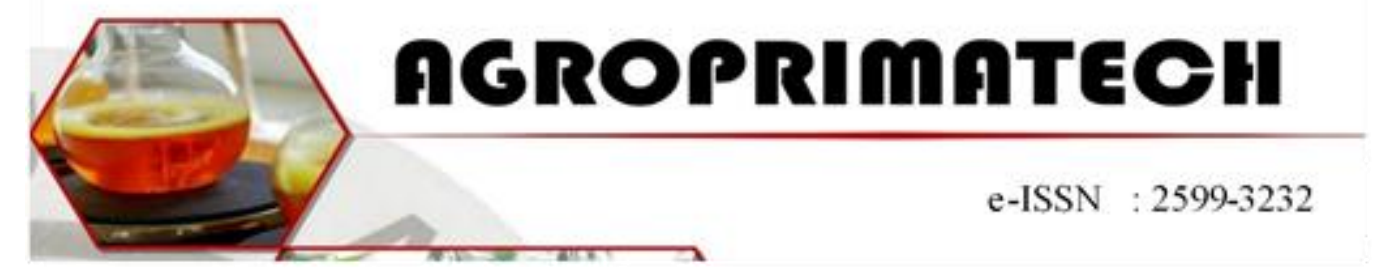

\title{
EKOLOGI ARTHROPODA PADA BEKAS SARANG ORANGUTAN SUMATERA (Pongo abelii) DI TAMAN NASIONAL GUNUNG LEUSER RESORT SEI BETUNG KECAMATAN BESITANG KABUPATEN LANGKAT, SUMATERA UTARA
}

\author{
HABIBULLAH ${ }^{1}$, BINARI MANURUNG ${ }^{2}$, JULAILI IRNI ${ }^{3}$ \\ ${ }^{1}$ Mahasiswa Biologi Fakultas Matematika Dan IImu Pengetahuan Alam Universitas Negeri \\ Medan \\ ${ }^{2}$ Dosen Biologi Fakultas Matematika Dan Ilmu Pengetahuan Alam Universitas Negeri \\ Medan \\ ${ }^{3}$ Dosen Fakultas Agro Teknologi Universitas Prima Indonesia \\ Email : mashabib15@gmail.com
}

\begin{abstract}
ABSTRAK
Penelitian ini dilakukan di Taman Nasional Gunung Leuser Resort Sei Betung Kecamatan Besitang Kabupaten Langkat Sumatera Utara pada bulan Januari 2014. Penelitian ini bertujuan untuk mengetahui keanekaragaman, kelimpahan, kemerataan, dominansi dan faktor fisika-kimia lingkungan. Penelitian ini menggunakan metode deskriptif survey. Pengambilan sampel dilakukan sebanyak 5 kali pengulangan. Hasil penelitian ditemukan Arthropoda yang termasuk ke dalam 23 famili, 12 ordo dan 3 kelas (Insekta, Arachinida dan Chilopoda). Kelimpahan total Arthropoda sebanyak 1700 individu. Indeks keanekaragaman pada pohon Aglaia sp. 2.37 dan pada pohon Phyllanthus 1.83. Indeks kesamaan 52\%. Indeks kemerataan pada pohon Aglaia sp. 0.73 dan pada pohon Phyllanthus 0.21. Indeks Dominansi pada pohon Aglaia sp. 0.13 dan pada pohon Phyllanthus 0.21 . Kisaran rata-rata suhu udara berkisar $26.4^{\circ} \mathrm{C}-28.2^{\circ} \mathrm{C}$, kisaran rata-rata suhu sarang $25.4^{\circ} \mathrm{C}-28^{\circ} \mathrm{C}$ dan kelembaban udara rata-rata berkisar $78 \%-85 \%$.
\end{abstract}

Kata Kunci: Arthropoda, Aglaia sp., Phyllanthus, TNGL, Ekologi.

\section{PENDAHULUAN}

Arthropoda adalah kelompok hewan beruas-ruas, bersendi atau bersegmen. Arthropoda merupakan filum terbesar dalam dunia Animalia yang saat ini diperkirakan terdapat 713.500 jenis Arthropoda dengan jumlah itu diperkirakan $80 \%$ yang sudah dikenal (Nurhadi, 2011; Irni et al, 2017).

Arthropoda memiliki peran yang sangat vital dalam rantai makanan khususnya sebagai dekomposer. Selain itu, arthropoda juga berperan sebagai mangsa bagi predator kecil yang lain, sehingga akan menjaga kelangsungan Arthropoda yang lain (Samudra, 2013).
Informasi mengenai ekologi Arthropoda pada bekas sarang orangutan hingga saat ini masih relatif terbatas, sementara Sumatera Utara dikenal sebagai salah satu habitat orangutan Sumatera (Pongo abelii) di dunia. Beberapa penelitian tentang sarang orangutan selama ini kebanyakan digunakan untuk parameter atau metode perkiraan kepadatan orangutan (Santosa \& Rahman, 2012). Sementara penelitian pohon sarang orangutan dilaporkan Sianipar (2013), Pujiyani (2009) dan Muin (2007).

Ekologi Arthropoda pada bekas sarang orangutan Sumatera (Pongo abelii) di Taman Nasional Gunung Leuser Resort Sei Betung informasinya 
masih relatif terbatas. Di samping itu kawasan tersebut sering digunakan sebagai tempat belajar siswa maupun tempat kegiatan kuliah lapangan atau praktek kerja lapangan oleh mahasiswa dari beberapa universitas di Sumatera Utara.

Pada tulisan ini dikaji ekologi Arthropoda pada bekas sarang orangutan Sumatera di Taman Nasional Gunung Leuser Resort Sei Betung. Tujuan penelitian ini mencakup keanekaragman, kelimpahan, kesamaan, Dominansi dan faktor fisika kimia pada pohon sarang Aglaia sp. (Meliaceae) dan pohon sarang Phyllanthus (Phyllanthaceae).

\section{METODE PENELITIAN}

Berdasarkan jenis pohon sarang orangutan di Resort Sei Betung ditetapkan 2 jenis pohon sarang yaitu pohon Aglaia sp. dan pohon Phyllanthus. Jumlah sarang yang dikoleksi pada tiap pohon sarang 5 buah, sehingga jumlah total sarang 10 buah. Pengambilan sampel sarang dilakukan bulan Januari 2014. Pada setiap sarang dilakukan pengukuran faktor fisika-kimia yaitu : suhu sarang, suhu udara dan kelembaban udara.

Metode dalam penelitian ini menggunakan metode deskriptif survey. Teknik pemisahan sampel Arthropoda dengan serasah bekas sarang yaitu dengan hand sorting dan Barlese-tullgren (Edward \& Fletcher dalam Bremner, 1990).

Seluruh Arthropoda pada bekas sarang orangutan yang berhasil dikoleksi kemudian dimasukkan ke dalam botol sampel yang berisi alkohol $70 \%$ dan selanjutnya diidentifikasi di Laboratorium Biologi Universitas Negeri Medan.
Identifikasi Arthropoda berdasarkan Borror (1996), Gillott (2005), Chu (1949), Anonim (1991) dan David \& Ananthakrishnan (2006).

Untuk menghitung keanekaragaman Arthropoda digunakan rumus indeks keanekaragaman Shannon-Wiener (Odum, 1993). Indeks kesamaan komunitas berdasarkan Sorensen (Odum, 1993), indeks kemerataan (evenness) berdasarkan Manurung (2013), indeks dominansi berdasarkan Simpson (Odum, 1993) sedangkan perbedaan keanekaragaman dan kelimpahan Arthropoda dihitung menggunakan uji Hutchinson (Rusmendro, 2009).

\section{HASIL DAN PEMBAHASAN}

\section{Faktor Fisika-kimia Sarang}

Keberadaan fauna sangat dipengaruhi oleh faktor lingkungan yaitu faktor biotik dan faktor abiotik. Faktor lingkungan abiotik yang mempengaruhi adalah faktor fisika dan faktor kimia. Sedangkan faktor biotik yang mempengaruhi antara lain mikroflora dan tanaman (Nusroh, 2007).

Pengukuran faktor fisika-kimia yang berperan sebagai lingkungan abiotik bagi hewan telah dilakukan di hutan sekunder Taman Nasional Gunung Leuser Resort Sei Betung. Hasil pengukuran faktor fisika-kimia disajikan pada Tabel 1.

Berdasarkan Tabel 1. dapat dikemukakan bahwa kisaran rata-rata suhu sarang pada pohon sarang Aglaia sp. adalah $25,4^{\circ} \mathrm{C}$, sedangkan pada pohon Phyllanthus adalah $28^{\circ} \mathrm{C}$. Hal ini menunjukan bahwa suhu sarang pada pohon sarang Phyllanthus relatif lebih tinggi bila di bandingkan dengan pohon Aglaia sp.

Tabel 1. Hasil pengukuran suhu sarang, suhu udara dan kelembaban udara pada pohon sarang orangutan.

\begin{tabular}{|c|c|c|c|c|}
\hline $\begin{array}{r}\text { Aglaia sp. } \\
\text { (Meliaceae) }\end{array}$ & & $\begin{array}{l}\text { Phy } \\
\text { hylla }\end{array}$ & $\begin{array}{l}\text { thus } \\
\text { ace }\end{array}$ & \\
\hline Ts $\mathrm{Tu}$ & $\mathrm{Rh}$ & Ts & $\mathrm{Tu}$ & $\mathrm{Rh}$ \\
\hline
\end{tabular}


Agroprimatech

Vol. 4 No. 1, Oktober 2020

e-ISSN :2599-3232

\begin{tabular}{llllll}
\hline 25,4 & 26,4 & 85 & 28 & 28,2 & 78
\end{tabular}

Keterangan

$$
\begin{aligned}
& \text { Ts }\left({ }^{\circ} \mathrm{C}\right)^{*} \text { suhu sarang } \\
& \text { Tu }\left({ }^{\circ} \mathrm{C}\right) * \text { suhu udara } \\
& \operatorname{Rh}(\%)^{*} \text { kelembaban udara }
\end{aligned}
$$

Sementara kisaran suhu udara pada tegakan pohon Aglaia sp. adalah $26,4^{\circ} \mathrm{C}$, sedangkan pada pohon Phyllanthus adalah $28,2^{\circ} \mathrm{C}$. Hal ini menunjukan bahwa suhu udara pada pohon sarang Phyllanthus lebih tinggi bila di bandingkan dengan suhu udara pohon Aglaia sp.

Suhu merupakan faktor pembatas terhadap pertumbuhan dan penyebaran hewan. Semua Arthropoda dapat dianggap sebagai hewan poikiloterm. Sehingga keberhasilan hidupnya sangat di pengaruhi lingkungan. Keberhasilan aktivitas dan mencari makan pada Insekta tergantung pada temperatur. Kisaran suhu udara antara $25^{\circ} \mathrm{C}$ sampai $30^{\circ} \mathrm{C}$ merupakan suhu optimal dan toleran bagi aktivitas Insekta di daerah tropis. Dalam hal ini Rahmawati (2004) menyatakan bahwa kisaran suhu yang optimal bagi Insekta, yaitu antara $29,6^{\circ} \mathrm{C}$ sampai $32,1^{\circ} \mathrm{C}$.

Dari penelitian di lapangan di peroleh data kelembaban udara rata-rata 78\%-85\% (Tabel 1). Kisaran kelembaban udara pada pohon sarang Aglaia sp. adalah $85 \%$ sedangkan pada pohon Phyllanthus 70\%-90\%. Kelembaban udara dapat dipengaruhi oleh intensitas

cahaya dan curah hujan. Kelembaban udara semakin tinggi jika intensitas cahaya semakin rendah. Sementara jika curah hujan tinggi maka kelemababan juga tinggi. Dalam hal ini Indriyanto (2012) melaporkan bahwa rata- rata kelembaban udara pada hutan hujan tropis adalah $80 \%$.

\section{Keragaman Arthropoda Bekas Sarang Orangutan Sumatera}

Dari hasil pengamatan terhadap bekas sarang orangutan Sumatera pada pohon sarang Aglaia sp. dan pohon sarang Phyllanthus ditemukan satu filum yaitu Arthropoda yang terdiri dari 3 kelas (Insekta, Arachinida dan Chilopoda). Bila ditinjau dari tinggkat ordo termasuk ke dalam 12 ordo.

Kelas Insekta yang ditemukan terdiri dari 9 ordo (75\%) yaitu Dermaptera, Blattellidae, Hymenoptera, Coleoptera, Hemiptera, Orthoptera, Lepidoptera, Tysanoptera dan Homoptera. Kelas Arachinida yang ditemukan terdiri dari 2 ordo (17\%) yaitu Pseudoscorpiones, Araneidae. Sedangkan kelas Chilopoda yang ditemukan hanya satu ordo (8\%) yaitu Scolopendromorpha (Gambar 1.)

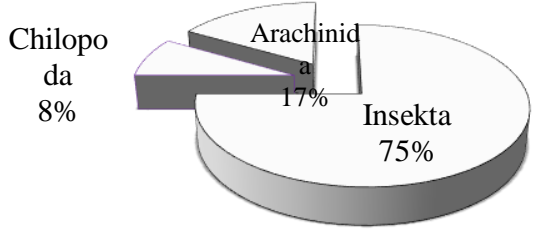

Gambar 1. Keanekaragaman Arthropoda pada bekas sarang orangutan.

Bila dilihat dari tingkat famili termasuk ke dalam 23 famili yaitu Forficulidae, Blattellidae, Formicidae, Salpingidae, Chrysomelidae, Staphylinidae, Histeridae, Nitiduliidae, Scrabaeidae, Reduviidae, Lygaeidae,
Cicadellidae, Geometridae, Noctuidae, Lymantridae, Tettgoniidae, Grylidae, Phaeothripidae, Thomisidae, Salticidae, Loxoscelidae, Chernetidae dan Scolopendridae. 
Kristofik (1994) melaporkan bahwa kumbang dari famili Histeridae, Staphylinidae, Scarabaeidae dan anggota kelas Arachinida seperti Pseudoscorpions, Araneidae dan Salticidae juga di temukan di sarang burung Sand Martin (Riparia riparia) di Slovakia. Lebih lanjut Kristofik (2009) melaporkan bahwa pada sarang burung Elang (Aquila pomarina) juga ditemukan kelompok kumbang Histeridae dan Staphylinidae kemudian ordo Pseudoscorpiones sedangkan kelas Arachinida dan Chilopoda masingmasing satu ordo. $A$. pomarina merupakan kelompok burung elang yang membangun sarang di atas pohon.

Kelompok kumbang staphylinidae dan Chrysomelidae juga ditemukan pada sarang bearbed tit (Panurus biarmicus) (Kristofik, 2007). Sementara dalam laporan Kristofik (2003) bahwa kelompok kumbang dari famili Histeridae, Tabel 2. Struktur kelimpahan komunitas Arthropoda pada pohon sarang Aglaia sp. dan pohon Phyllanthus.

\begin{tabular}{lcc} 
Keteranagan & Aglaia sp. & Phyllanthus \\
& & \\
\hline Jumlah Filum & 1 & 1 \\
Jumlah Kelas & 3 & 3 \\
Jumlah Ordo & 12 & 12 \\
Jumlah Famili & 18 & 20 \\
Jumlah individu & 697 & 1003 \\
\hline$\Sigma$ & & 1700 individu \\
\hline
\end{tabular}

Staphylinidae, Scarabaidae dan Nitiduliidae ditemukan pada sarang burung hantu tengamamlm's owl (Aegolius funereus).

Hasil penelitian menunjukkan kecendrungan populasi Insekta yang paling tinggi pada kedua jenis pohon sarang. Dalam hal ini sesuai pernyataan Borror (1996) bahwa Insekta merupakan golongan hewan yang dominan di muka bumi.

Berdasarkan tabel 2. jumlah total Arthropoda pada kedua tipe jenis pohon sarang diperoleh sebanyak 1700 individu. Jumlah famili dan individu Arthropoda bekas sarang orangutan yang dikoleksi pada pohon sarang Aglaia sp. dan pohon Phyllanthus bervariasi. Pada pohon sarang Aglaia sp. tergolong ke dalam 12 ordo dengan 18 famili (697 individu) sedangkan pada pohon sarang Phyllanthus 12 ordo dengan 20 famili (1003 individu).

Tabel 3. Struktur komunitas Arthropoda pada bekas sarang orangutan (keanekaragaman kelimpahan, dominansi, kesamaan dan kemerataan).

\begin{tabular}{|c|c|c|c|c|c|c|c|c|}
\hline \multirow[t]{2}{*}{ Ordo } & \multirow[t]{2}{*}{ Famili } & \multicolumn{3}{|c|}{$\begin{array}{l}\text { Aglaia sp. } \\
\text { (Meliacea) }\end{array}$} & \multicolumn{3}{|c|}{$\begin{array}{c}\text { Phyllanthus } \\
\text { (Phyllanthaceae) }\end{array}$} & \multirow[t]{2}{*}{$\Sigma$} \\
\hline & & HS & BT & $\Sigma$ & HS & BT & $\Sigma$ & \\
\hline Dermaptera & Forficulidae & 196 & 3 & 199 & 349 & 11 & 360 & 559 \\
\hline Blattaria & Blattelidae & 104 & - & 104 & 42 & - & 42 & 162 \\
\hline Hymenoptera & Formicidae & 155 & 5 & 160 & 226 & 4 & 230 & 390 \\
\hline \multirow{6}{*}{ Coleoptera } & Salpingidae & 17 & - & 17 & 48 & 1 & 49 & 66 \\
\hline & Chrysomelidae & 10 & - & 10 & 6 & - & 6 & 15 \\
\hline & Nitiduliidae & 2 & - & 2 & - & - & - & 2 \\
\hline & Staphylinidae & 31 & - & 31 & 18 & - & 18 & 2 \\
\hline & Scarabaeidae & 32 & - & 32 & - & - & - & 32 \\
\hline & Histeridae & - & - & - & 1 & - & 1 & 1 \\
\hline \multirow[t]{2}{*}{ Orthoptera } & Tettgoniidae & 1 & - & 1 & 1 & - & 1 & 1 \\
\hline & Gryllidae & 2 & - & 2 & 1 & - & 1 & 3 \\
\hline
\end{tabular}


Agroprimatech

Vol. 4 No. 1, Oktober 2020

e-ISSN :2599-3232

\begin{tabular}{|c|c|c|c|c|c|c|c|c|}
\hline Thysanoptera & Phaeothipidae & 19 & 1 & 20 & 40 & 2 & 42 & 62 \\
\hline \multirow{2}{*}{ Hemiptera } & Lygaeidae & - & 1 & 1 & 2 & - & 2 & 3 \\
\hline & Reduviidae & 11 & 1 & 12 & 3 & - & 3 & 15 \\
\hline Homoptera & Cicadellidae & - & - & - & 1 & - & 1 & 1 \\
\hline \multirow[t]{3}{*}{ Lepidoptera } & Geometridae & - & - & - & 5 & - & 5 & 5 \\
\hline & Noctuidae & 65 & - & 65 & 214 & 1 & 215 & 286 \\
\hline & Lymantridae & - & - & - & 6 & - & 6 & \\
\hline \multirow[t]{3}{*}{ Araneidae } & Thomisidae & 15 & - & 15 & - & - & - & 15 \\
\hline & Salticidae & 1 & - & 1 & 10 & - & 10 & 11 \\
\hline & Loxoscelidae & - & - & - & 1 & - & 1 & 1 \\
\hline Pseudoscorpiones & Chernetidae & 24 & - & 24 & 6 & - & 6 & 30 \\
\hline $\begin{array}{l}\text { Scolopendromorp } \\
\text { ha }\end{array}$ & $\begin{array}{l}\text { Scolopendrida } \\
\mathrm{e}\end{array}$ & 1 & - & 1 & 4 & - & 4 & 5 \\
\hline$\Sigma$ & & 686 & 11 & 697 & 984 & 19 & 1003 & 1007 \\
\hline$H^{\prime}$ & & 2.31 & 1.66 & 2.37 & 1.90 & 1.88 & 1.83 & \\
\hline SD & & 0.32 & 0.56 & 0.34 & 0.41 & 1.14 & 0.38 & \\
\hline Indeks & & 0.71 & 0.93 & 0.73 & 0.59 & 0.73 & 0.57 & \\
\hline $\begin{array}{l}\text { kemerataan } \\
\text { SD }\end{array}$ & & 0.90 & 0.51 & 0.11 & 0.15 & 1.02 & 0.15 & \\
\hline Indeks dominansi & & 0.13 & 0.20 & 0.13 & 0.21 & 0.39 & 0.21 & \\
\hline SD & & 0.11 & 0.20 & 0.10 & 0.14 & 0.31 & 0.14 & \\
\hline Indeks kesamaan & & & & & & & & $52 \%$ \\
\hline Uji Hutchinson & & 65 & hit & $3 e r$ & a & $t \mathrm{si}$ & kan & \\
\hline
\end{tabular}

Keterangan: $\mathrm{HS}^{*}$ hand sorting, $\mathrm{BT}^{*}$ barlese tullgren, $\mathrm{SD}^{*}$ standart deviasi

Indeks Keanekaragaman Arthropoda

Setelah dilakukan analisis dengan menggunakan indeks ShannonWiener diperoleh hasil, pada pohon Aglaia sp. memiliki indeks keanekaragaman 2.37 sedangkan pada pohon Phyllanthus $\left(H^{\prime}=1.83\right)$ (Gambar 2).
Bila ditinjau dari metode yang dilakukan, metode hand sorting pada pohon Aglaia sp. (H'2.31) sedangkan barlese-tullgren $\left(H^{\prime}=1.66\right)$. Pada pohon Phyllanthus dengan metode hand sorting $\left(H^{\prime}=1.90\right)$ sedangkan barlese-tullgren $\quad\left(H^{\prime}=1.18\right)$ (Gambar 3).

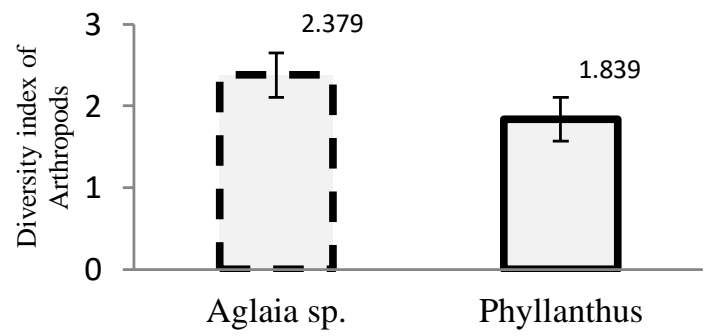

Gamabr 2. Indeks keanekaragaman Arthropoda pada bekas sarang orangutan yang terdapat pada pohon Aglaia sp. dan pohon Phyllanthus.

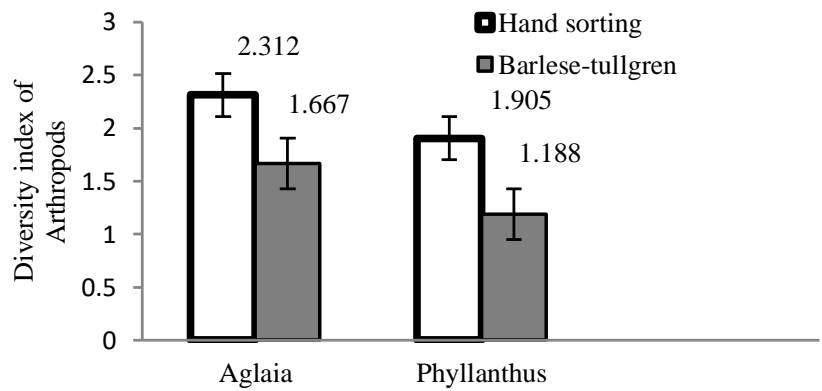


Gambar 3. Indeks keanekaragaman Arthropoda pada bekas sarang orangutan berdasarkan metode hand sorting dan barlese-tullgren.

Sehingga indeks keanekaragaman Arthropoda pada penelitian ini berdasarkan kriteia nilai indeks Shannon-Wiener tersebut di kategorikan sedang. Hal ini menunjukkan bahwa kualitas lingkungan pada bekas sarang orangutan cukup baik dalam mendukung kehidupan Arthropda. Stabilitas lingkungan dan jaring-jaring makanan yang terdapat di dalam bekas sarang orangutan cukup stabil bagi komunitas Arthropoda. Keanekaragaman di pengaruhi oleh spesies tanaman, komposisi tanaman, ketersediaan sumber makanan, baik dari mikroorganisme maupun yang lain (Samudra, 2013).

Dalam hal ini Manurung (2013) menyatakan bahwa ekosistem yang baik memiliki indeks keanekaragaman relatif tinggi sebaliknya ekosistem yang buruk memiliki indeks keanekaragaman yang cendrung rendah.

\section{Indeks Kesamaan Komunitas}

Kedua komunitas jenis pohon sarang (pohon Aglaia sp. dan pohon Phyllathus) memiliki indeks kesamaan
Arthropoda sebesar 52\%. Aturan 50\% terhadap dua komunitas yang dibandingkan bila lebih besar dari $50 \%$ maka kedua komunitas tersebut dapat dianggap satu komunitas. Hal ini ditegaskan Dewi dalam Peritika (2010) bahwa dua komunitas dianggap sama apabila memiliki nilai indek similaritas > $50 \%$. Berdasarkan aturan 50\% tersebut maka dua jenis pohon sarang tersebut dapat dikatakan satu komunitas.

\section{Indeks Kemerataan (Evenness)}

Pohon Aglaia sp. memiliki indeks kemerataan 0.73 sedangkan pada pohon Phyllanthus memiliki indeks kemerataan 0.57 (Gambar 4). Pohon Aglaia sp. dengan metode hand sorting memiliki indeks kemerataan 0.71 sedangkan dengan barlese-tullgren 0.93. Sementara pada pohon Phyllanthus dengan hand sorting memiliki indeks kemerataan 0.59 sedangkan dengan barlese-tullgren memiliki indeks kemerataan 0.73 (Gambar 5). Hasil perbandingan indeks keanekaragaman memperlihatkan bahwa pohon sarang Aglaia sp. menjadi mikrohabitat yang lebih stabil daripada pohon sarang Phyllanthus.

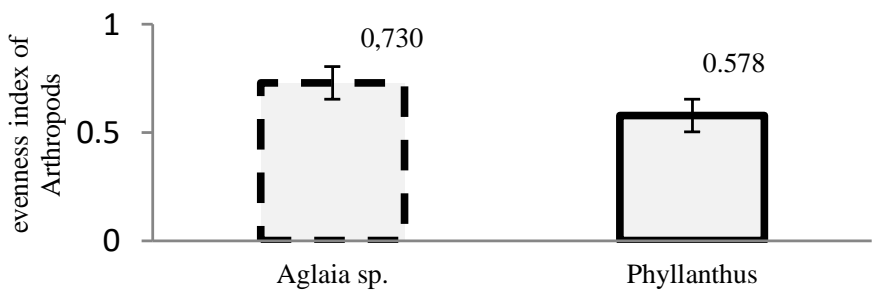

Gambar 4. Indeks kemerataan Arthropoda pada bekas sarang orangutan yang terdapat pada pohon Aglaia sp. dan pohon Phyllanthus

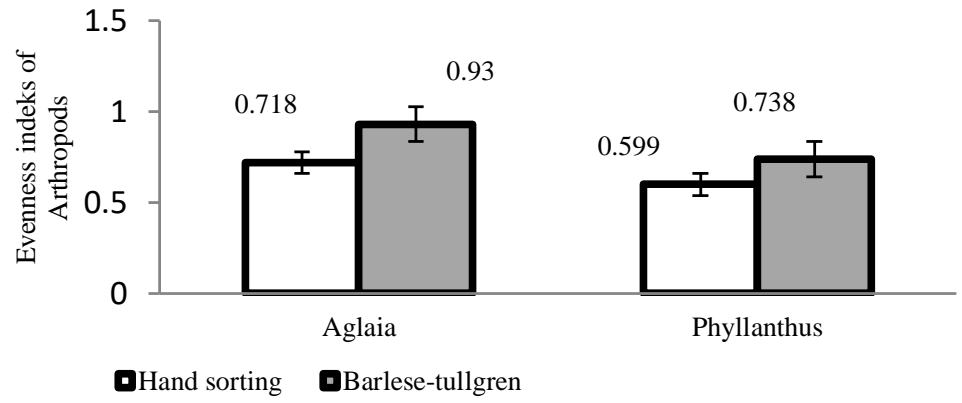


Gambar 5. Indeks kemerataan Arthropoda pada bekas sarang orangutan yang terdapat pada pohon Aglaia sp. dan pohon Phyllanthus berdasarkan metode hand sorting dan barlese-tullgren.

Manurung (2013) bahwa semakin tinggi indeks kemerataan suatu komunitas, maka komunitas itu akan semakin stabil. Sehingga kondisi seperti itu proporsi masing-masing spesies pembentuk komunitas semakin seimbang artinya speseies yang dominan relatif tidak ada.

\section{Indeks Dominansi Arthropoda}

Pohon Aglaia sp. memiliki indeks dominansi 0.13 sedangkan pohon Phyllanthus memiliki indeks dominansi 0.21 (Gambar 6). Pada pohon Aglaia sp. dengan metode hand sorting memiliki indeks dominansi 0.13 sedangkan dengan barlese-tullgren 0.205 . Sementara pada pohon Phyllanthus dengan metode hand sorting memiliki indeks dominansi 0.21 sedangkan dengan barlese-tullgren 0.39 (Gambar 7). Berdasarkan kriteria nilai indeks dominansi Simpson (0-1) maka indeks dominansi pada penelitian ini di kategorikan rendah. Hal ini menunjukan bahwa pohon sarang Aglaia sp. menjadi mikrohabitat yang lebih stabil bila dibandingkan dengan pohon sarang Phyllanthus.

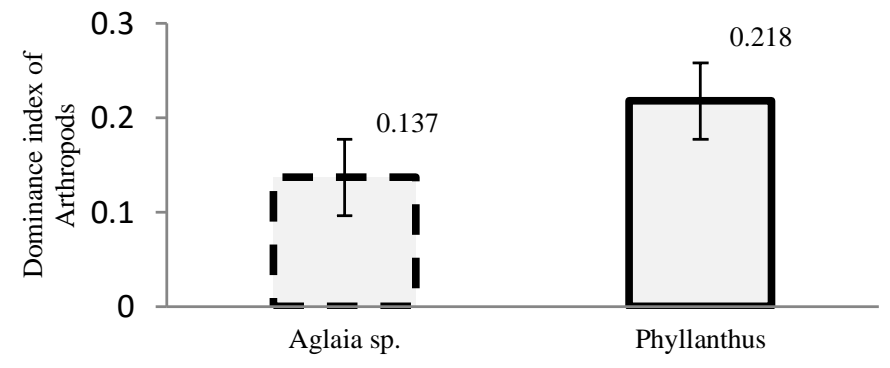

Gambar 6. Indeks dominansi Arthropoda pada bekas sarang orangutan yang terdapat pada pohon Aglaia sp. dan pohon Phyllanthus.

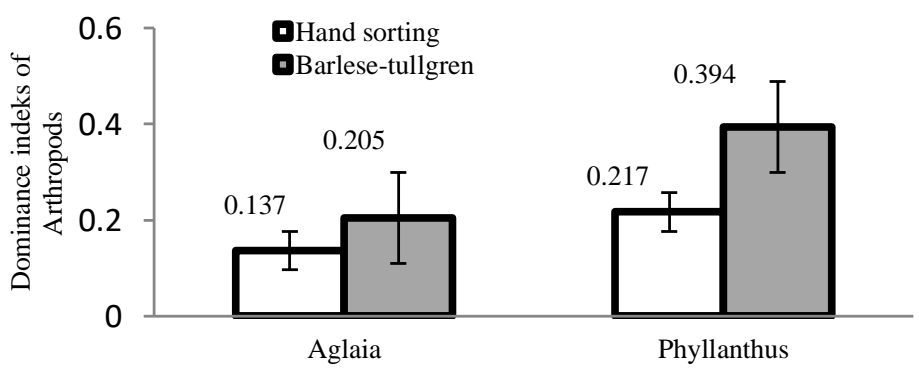

Gambar 7. Indeks dominansi Arthropoda pada bekas sarang orangutan yang terdapat pada pohon Aglaia sp. dan pohon Phyllanthus berdasarkan metode hand sorting dan barlese-tullgren

\section{Perbedaan Keanekaragaman dan Kelimpahan Komunitas Arthropoda pada Bekas Sarang Orangutan}

Berdasarkan uji Hutchinson diperoleh nilai t-hitung $=90>\mathrm{t}$-tabel 1.65 Karena nilai t-hitung lebih besar daripada t-tabel pada taraf kepercayaan 95\% ( $\alpha=$ $0,05)$ maka terdapat perbedaan signifikan antara keanekaragaman dan kelimpahan Arthropoda pada bekas sarang orangutan Sumatera antara pohon sarang Aglaia sp. dan pohon Phyllanthus. 
Tabel 4. Perbedaan keanekaragaman dan kelimpahan komunitas Arthropoda pada bekas sarang orangutan Sumatera.

\begin{tabular}{|c|c|c|c|}
\hline Habitat & t-tab & t-hit & perbedaan \\
\hline $\begin{array}{c}\text { Aglaia sp. } \\
\&\end{array}$ & 1.65 & 90 & Berbeda sangat nyata \\
Phyllanthus & & & \\
\hline
\end{tabular}

\section{KESIMPULAN}

1. Keanekaragaman Arthropoda pada bekas sarang orangutan Sumatera yang ditemukan adalah terdiri 23 famili, 12 ordo dan 3 kelas.

2. Kelimpahan total Arthropoda ditemukan adalah 1700 individu. Pada pohon sarang Aglaia sp. ditemukan 697 individu sedangkan pada pohon sarang Phyllanthus ditemukan 1003 individu.

3. Indeks keanekaragaman yang diperoleh pada pohon Aglaia sp. adalah 2.37 sedangkan pada pohon Phyllanthus 1.83. Hasil tersebut di kategorikan sedang.

4. Indeks kesamaan Arthropoda yang diperoleh sebesar $52 \%$. Sehingga di kategorikan satu komunitas.

\section{Saran}

1. Perlu dilakukan penelitian lanjutan terhadap Arthropoda pada bekas sarang orangutan Sumatera sehubungan dengan bahan organik sarang.

2. Perlu adanya penelitian lanjutan untuk mengetahui keanekaragaman dan kelimpahan Arthropoda pada berbagai pohon sarang yang beragam, di samping pohon sarang Aglaia sp. dan pohon Phyllanthus.

\section{Prospek}

a. Menambah keanekaragaman kajian ilmu biologi terutama keanekaragaman Arthropoda pada bekas sarang orangutan.
5. Indeks kemerataan pada pohon sarang Aglaia sp. yang diperoleh adalah 0.73 sedangkan pada pohon sarang Phyllanthus 0.57.

6. Indeks dominansi pada pohon sarang Aglaia sp. sebesar 0.13 sedangkan pada pohon sarang phyllanthus 0.21 sehingga indeks dominansi di kategorikan rendah.

7. Kisaran suhu sarang pada Aglaia sp. berkisar $25^{\circ} \mathrm{C}-27^{\circ} \mathrm{C}$, suhu udara berkisar $26^{\circ} \quad \mathrm{C}-28^{0} \quad \mathrm{C}$ dan kelembaban udara berkisar 85\%. Sedangkan kisaran suhu sarang pada pohon sarang phyllanthus berkisar $27^{\circ} \mathrm{C}-29^{\circ} \mathrm{C}$, suhu udara berkisar $26^{\circ} \quad \mathrm{C}-30^{\circ} \quad \mathrm{C}$ dan kelembaban udara berkisar 70\%$90 \%$.

b. Memberikan informasi kepada instansi terkait seperti Balai Besar Taman Nasional Gunung Leuser dan masyarakat mengenai keanekaragaman Artropoda pada sarang orangutan di hutan sekunder Taman Nasional Gunung Leuser Resort Sei Betung Kecamatan Besitang Kabupaten Langkat. Sehingga konservasi untuk melindungi orangutan dapat lebih ditingkatkan

c. Sebagai bahan informasi dalam identifikasi Arthropoda pada sarang orangutan yang selanjutnya dapat di jadikan referensi penelitian lanjutan.

\section{DAFTAR PUSTAKA}

Anonim. 1991. Kunci determinasi serangga. Yogyakarta: Kanisius. 
Borror, D.J., C.A. Triplehorn, N.F. Johnson. 1996. Pengenalan Pelajaran Serangga. Yogyakarta: Gadjah Mada University Press.

Bremner, G. 1990. A Balese funnel for the rapid extraction of grassland surface macro-arthropoda. New Zealand Entomologist. 13: 7680.

Chu, H.F. 1949. How to Know the Immature Insects. Dubugue, Lowa: WM. C. Brown Company Publishers.

David, B.V., T.N. Ananthakrishnan. 2006. General and applied entomology. India New Delhi: McGraw-Hill.

Gillot, C. 2005. Entomology third edition. Netherlands: Springer.

Indriyanto. 2013. Ekologi hutan. Jakarta: Bumi Aksara.

Irni, J., Masy'ud, B., \& Haneda, N. F. 2017. Keanekaragaman jenis kupu-kupu berdasarkan tipe tutupan lahan dan waktu aktifnya di kawasan penyangga Tangkahan Taman Nasional Gunung Leuser. Media Konservasi, 21(3), 225-232.

Kristofik, J., Masan, P., Sustek, Z., Karaska, D. 2009. Arthropoda in the nest of Lesser Spotted eagle (Aquila pomarina). Biologia. 64 (5): 974-980.

Kristofik, J., Z. Sustek, P. Gajdos. 1994. Arthropoda in nests of the Sand Martin (Riparia riparia Linnaeus

1758) in South Slovakia. Biologi, Bratislava. 49 (5): 683-690.

Kristofik, J., Masan, P., Z, Sustek. 2007. Arthropods

(Pseudoscorpionidae, Acarina, Coleoptera, Siphonoptera) in nest of the bearded tit (Panurus biarmicus). Biologia,Brastislava. 62 (6): 749-755.

Kristofik, J., P, Masan., Z, Sustek., B, Kloubec. 2003. Arthropods (Pseudoscorpionida, Acari, Coleoptera, Siphonaptera) in nests of the tengmalm's owl
(Aegolius funereus). Biologia, Brastaliva. 58 (2): 231-240.

Manurung, B. 2013. Ekologi Hewan. Medan: Universitas Negeri Medan.

Muin, A. 2007. Tipologi Pohon Tempat Bersarang dan Karaktersistik Sarang Orangutan (Pongo pygmeaus wurumbi) di Taman Nasional Tanjung Puting. Tesis. Bogor: Sekolah Pasca Sarjana IPB.

Nurhadi. 2011. Komposisi Arthropoda Permukaan Tanah Di Kawasan Pabrik Pupuk Sriwijaya Palembang. Sumatera Barat. Jurnal IImiah Ekotrans Universitas Ekasakti Padang. 11 (1): 1-11.

Nusroh, Z. 2007. Studi diversitas makrofauna tanah di bawah beberapa tanaman palawija yang berbeda di lahan kering pada saat musim penghujan. Skripsi. Surakarta: Fakultas Pertanian, Universitas Sebelas Maret.

Odum, E. P. 1993. Dasar-dasar ekologi. Yogyakarta: Gadjah Mada University Press.

Peritika, M.Z. 2010. Keanekaragaman makrofauna tanah pada berbagai pola agroforestri lahan miring di Kabupaten Wonogiri, Jawa Tengah. Skripsi. Surakarta: Fakultas Matematika dan IImu Pengetahuan Alam, Universitas Sebelas Maret.

Pujiyani, H. 2009. Karakteristik Pohon Tempat Bersarang Orangutan Sumatera (Pongo abelii) di Kawasan Hutan Batang Toru Kabupaten Tapanuli Utara Sumatera Utara. Skripsi. Bogor: Fakultas Kehutanan, Institut Pertanian Bogor.

Rahman, D.A. 2010. Karakteristik Habitat dan Preferensi Pohon Sarang Orangutan ,

(Pongo pygmaeus wurmbii) di Taman Nasional Tanjung Puting (Studi Kasus Camp Leakey). Jurnal 
Agroprimatech

Vol. 4 No. 1, Oktober 2020

Primatologi Indonesia. 7 (2): $37-$ 50.

Rahmawaty. 2004. Studi keanekaragaman mesofauna tanah di kawasan Hutan Wisata Alam Sibolangit. Medan: Fakultas Pertanian Universitas Sumatera Utara.

Rusmendro, H. 2009. Perbandingan keanekaragaman burung pada pagi dan sore hari di tempat tipe habitat di wilayah Pangandaran, Jawa Barat. Vis Vitalis. 2 (1). 816.

Samudra, F.B., M. Izzati, H. Purnaweni. 2013. Kelimpahan dan keanekaragaman Arthropoda tanah di lahan sayuran organik "Urban Farming" : Universitas
e-ISSN :2599-3232

Diponegoro. Prosiding Seminar Nasional

Pengelolaan Sumberdaya Alam dan Lingkungan. hlm 190-196.

Santosa, Y. dan Rahman. 2012. Ketelitian Metode Sarang untuk Pendugaan Populasi Orangutan dan Penentuan Faktor Ekologi Penting dalam Manajemen Hutan Konservasi. JMHT. XVIII (1): 39-51.

Sianipar, H.F. 2013. Identifikasi tanaman penyusun sarang Orangutan Sumater (Pongo abelii) di Besitang Taman Nasional Gunung Leuser Sumatera Utara. Skripsi. Medan: Universitas Negeri Medan. 